\title{
Biogas from Marine Macroalgae: a New Environmental Technology - Life Cycle Inventory for a Further LCA
}

\author{
Francesco Romagnoli, Institute of Energy Systems and Environment, Riga Technical University, Dagnija Blumberga, \\ Institute of Energy Systems and Environment, Riga Technical University, Emanuele Gigli, CIRPS, Inter-university \\ Research Centre for Sustainable Development - University of Rome "La Sapienza"
}

\begin{abstract}
The main goal of this paper is to analyze the innovative process of production of biogas (via fermentation processes) using marine macroalgae as feedstock in a pilot project plant in Augusta (Sicily, Italy). Algae, during their growth, have the capacity to assimilate nutrients and thus subsequent harvesting of the algal biomass recovers the nutrients from biowaste sources giving the possibility to transform negative environmental externalities in positive mainly in terms of eutrophication and climate change impact categories.

The paper presents a novel environmental technology for the production of biogas and $2^{\text {nd }}$ generation biofuel (liquid biomethane) after an upgrading process through the use of a cryogenic technology. The paper would also like to make the first attempt at understanding the possibility to implement this innovative technology in the Latvian context.

The first calculations and assumptions for the Life Cycle Inventory for a further Life Cycle Assessment are presented.
\end{abstract}

Keywords - biogas, biomethane, LCA, marine macro algae, Ulva Prolifera.

\section{INTRODUCTION}

The European Commission Green (Directive 2009/28/EC, [1]) paper takes into account the consideration of the main conceptions of the Kyoto protocol outlining options for a future strategy of a Community energy policy after the United Nations Climate Change Conference in Bali December 2007 where two ambitious key targets were set: a reduction of $20 \%$ of GHG by 2020 , and a $20 \%$ share of renewable energies in EU energy consumption by 2020.

At the moment, in Latvia, the share of electricity produced from Renewable Energy Sources (RES) is attested at the value of $42.4 \%$ but should increase to $49.3 \%$ (Directive 2007/71/EC [2], Directive 2009/28/EC [1]). At the same time, the share of renewable energy resources in the final energy consumption for 2020 should reach the level of $40 \%$ from $30 \%$ (Directive 2009/28/EC [1]). In this context, land filling of biowaste - that is one of the major sources of methane emissions in Europe (2\% of GHG emissions in 2007) - must foresee the reduction of biodegradable waste to $35 \%$ of 1995 levels by 2016 according to the EC Landfill Directive [3].

The Council Directive 91/676/EEC4 [4], has also underlined the need to control the reduction of water pollution caused by nitrates from wastes to protect human health, living resources and aquatic ecosystems and additionally attention is being focused on the treatment of biowaste.
Moreover the recent report of the Food and Agriculture Organisation [5] underlines the need to focus on 'non-food' energy crops for the production of $2^{\text {nd }}$ generation biofuels and to develop cost-efficient solutions which directs even more attention to the importance of biofuels production. In fact, currently, the production of biogas is principally carried out through anaerobic fermentation of (mixed) cereal crops. Hence, the need to further explore new feedstock sources for biofuels is a fundamental issue and the improvement of knowhow about second generation biofuel technology production is the natural consequence.

In this direction the development of technologies for the use of biowaste as a nutrient feedstock for algae growing and algae itself as a catalyst for producing biofuels is a novel field to be investigated.

Production of algae as a second generation biofuel feedstock has been the subject of research in this last decade. If used as an interface between biowaste and energy production, macroalage allows direct utilization of biowaste and, at the same time transforms negative environmental externalities into positive ones. A Life cycle assessment (LCA) of the overall process from cradle to grave is fundamental in order to optimize the overall process from the environmental point of view, thus addressing the environmental "hot spots" in the process.

In fact the constant increase of the use of biofuels immediately addresses the issue of reducing the use of nonrenewable resources (fossil fuels) and the impacts on climate change (especially carbon dioxide and the resulting greenhouse effect) but it does not always address the notion of overall improvement. For instance, it is well understood that conversion of biomass to bio-energy requires additional energy inputs, most often provided in some form of fossil fuel: hence a holistic approach of the overall production system of the biofuels is needed. In this context the tool offered by the LCA methodology seems a suitable instrument for understanding the environmental benefits and the share of non-renewable sources still needed for the process. Through the LCA approach it has also been demonstrated that even if the life cycle energy balance of a biofuel compared to a conventional fossil fuel should be positive, in fact, depending on the processing choices, the cumulative fossil energy demand might, at times, only be marginally lower or even higher than that of liquid fossil fuels [6]. 
In this paper, after a brief description of the main processes regarding a two-stage bioreactor system for the production of biogas, the example of a biogas plant included in the pilot project biowalk4biofuels [7] will be described. The pilot project is devoted to the construction of a biogas plant using macro algae as feedstock and poultry manure (or other biowastes rich in nitrogen and phosphate) as inoculum both for algae growing and for the biodigesters. The project has to be implemented in 4 years from April 2010 till April 2014. The second part will be mainly addressed on the aspects and calculations for building up the LCA system model taking into account: the base flow chart needed for the model, the choice of the possible functional units and main impact categories to be investigated, the first calculations regarding the amount of algae produced in the system in correlation to the final expected biogas production, and the basis for the LCA inventory. In the last part some preliminary aspect in terms of avoided impact from $\mathrm{CO}_{2}$ is also described together with some aspects regarding the possibility to implement this technology in Latvian conditions.

\section{PRODUCTION OF BIOGAS FROM ALGAE}

Biomass has been defined as a contemporary plant matter formed by photosynthetic capture of solar energy and stored as chemical energy.

The recent oil crisis and the consequent price increases have spawned considerable interest in the exploration of renewable energy sources. Bioenergy will be the most significant renewable energy source in the next few decades until solar or wind power production offers an economically attractive large-scale alternative. The energy that biomass contains can be reclaimed by various methods.

As mentioned before marine macro algae represent a good feedstock for production of second generation biofuels.

In this context the utilization of biowaste can be seen as an excellent use for feeding algae growing ponds and ideally, to fully meet a plant's energy supply through renewable energy sources. The means the feeding of the algae ponds can be conducted via animal litter digesters (e.g. poultry manure), water from the waste water treatment plant and/or industrial purified water. In the process the volatile solids (VS) would be converted to biogas. The biogas would be then combusted to produce electrical and thermal energy for the algae farm, and the exhaust (carbon dioxide) reused by the pond water. In fact, the algae-based plant should be theoretically energy selfsufficient, since the biogas should be sufficient for all the energy required by the overall plant [8].

Moreover the wastewater-grown biomass would contain sufficient levels of fatty acids (FA) to compete with other potential feedstocks. Although there is renewed interest in the production of algae for biofuel, there are few reports of the biofuel potential of wastewater-grown algae [9].

One of the methods used to convert algae into biogas is a two-stage fermentation process [10]. The same is implemented in the pilot plant analyzed placed in Augusta (Sicily, Italy). In a two-stage digester, the residual substrates from the first stage can be reduced at the second-stage digester, carrying out the same reactions as the first stage but running at a different retention time. For rapidly fermentable wastes, a two-stage reactor can have a lower overall retention time than a single stage. The second stage could be a stirred tank or a plug-flow digester or an anaerobic filter [5].

The anaerobic microbiological decomposition is the process necessary to obtain biogas from algae. The biogas produced without any upgrading is a mix of several gases with the main share allocated to biomethane and carbon dioxide. After the algae harvesting step, the biological process involves microorganisms to derive energy and grow by metabolising organic material in an oxygen-free environment resulting in the production of methane $\left(\mathrm{CH}_{4}\right)$. The anaerobic digestion process can be subdivided into the following four phases [11], each requiring its own characteristic group of micro-organisms:

- Hydrolysis: conversion of non-soluble biopolymers to soluble organic compounds,

- Acidogenesis: conversion of soluble organic compounds to volatile fatty acids (VFA) and $\mathrm{CO}_{2}$,

- Acetogenesis: conversion of volatile fatty acids to acetate and $\mathrm{H}_{2}$,

- Methanogenesis: conversion of acetate and $\mathrm{CO}_{2}$ plus $\mathrm{H}_{2}$ to methane gas.

A simplified schematic representation of the anaerobic degradation of organic matter is given in Figure 1. The acidogenic bacteria excrete enzymes for hydrolysis and convert soluble organics to volatile fatty acids and alcohols. Volatile fatty acids and alcohols are then converted by acetogenic bacteria into acetic acid or hydrogen and carbon dioxide. Methanogenic bacteria then use acetic acid or hydrogen and carbon dioxide to produce methane.

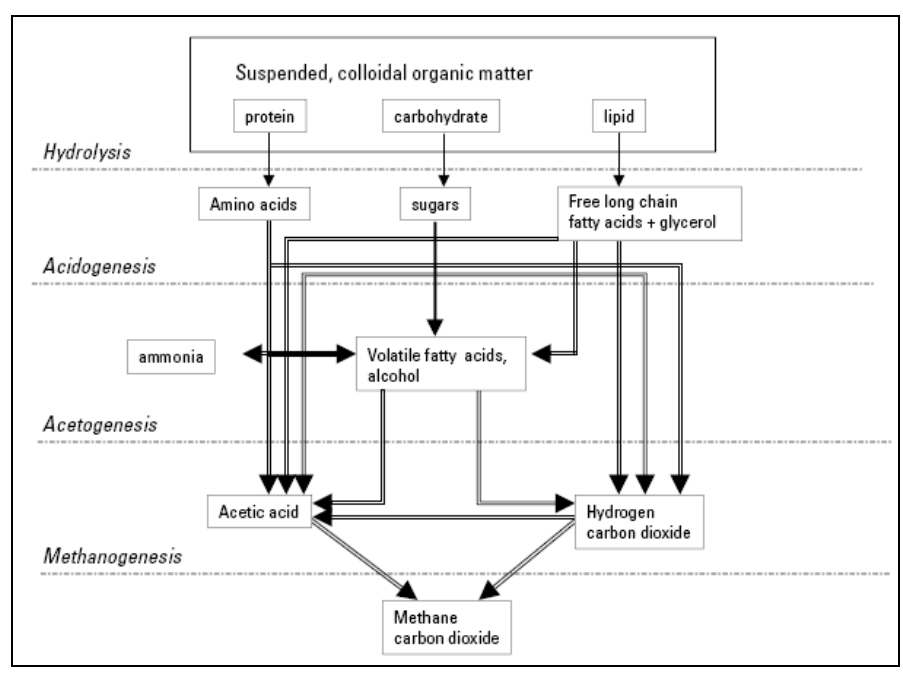

Fig. 1. Simplified schematic representation of the anaerobic degradation process [11].

In order to increase the growing rate yield of algae, the initial mass can be provided by protoplasts. Protoplasts are living plant or algae cells without cell walls which offer a unique uniformed single cell system that facilitates several aspects of modern biotechnology. The main application of many protoplast studies is to produce somatic hybrids through 
protoplast fusion in order to obtain fast growing algae species [12].

The use of protoplasts as feedstock for cultivation in an incubator under a controlled condition allows a higher regeneration rate. This type of cultivation in an incubator results in an increased productivity of cultivation and a higher biomass yield.

\section{PLANT DESCRIPTION}

The following section will describe the production of biogas obtained in the plant placed in Augusta included in the pilot project biowal4biofuels. The biomass comes from the open ponds in the open sea in front of the plant site and the collected biowaste is pumped in a hydrocyclone for the removal of sand. This removal process is to avoid damage to the stirred hydrolysis and acidification reactor.

The acidification phase (in a complete mixing anaerobic digester) will be carried out at $38^{\circ} \mathrm{C}$. The use of a thermophilic process accelerates the macromolecule demolition. After this first phase, the effluent is clarified: the solid part is then recycled to complete the hydrolysis, while the liquid part will pass through the second phase for methanation. The system is then fitted with instruments for the automatic control of the mechanical operations and the acidification reaction trend.

The second phase of the anaerobic digestion uses biomass patented rotors, "Archimedes Rotors", to maintain a high concentration of bacterial methanogenic flora and optimize the stripping of biogas.

The direct use of biowaste in biodigestors is problematic due to the heterogeneity of the compound and the high nitrogen content (e.g. in poultry manure). This causes problems in the fermentation process, so the introduction of other biomasses (e.g. cereal crops) or other complex pretreatments are usually required in order to have a homogenous mixture within the biodigestors. A low quality biogas is produced that requires adequate treatment and does not provide advantages in terms of eutrophication due to large amounts of liquid discharge during the anaerobic process [13].

The scheme of the plant is briefly described in Figure 2.

The system is centered on a two-stage bioreactor for production of biogas through anaerobic digestion using marine macroalgae as feedstock and in this part of the plant all the processes of biological anaerobic decomposition occur.

The biogas mix, after being collected, is sent to the biogas treatment plant where the removal of $\mathrm{H}_{2} \mathrm{~S}$ takes place. At the same time, the outflows from the digestion phase are carried to a stainless pool for the clarification process. In this phase the solid part is removed from the liquid, in order to, after drying, obtain pellets and fertilizers. The liquid fraction is indented to be reused in the open ponds for algae growing. This is a good way to reuse the co-products of the biogas production with a consequential decrease of the total environmental impact of the plant.

The pilot plant foresees (at the end of the second of the four project years) the implementation of an innovative cryogenic technology for optimizing the process obtaining a costefficient liquid biogas (LBG) for the production of biomethane destined to be used as energy carrier for transportation purposes.

The foreseen production of biogas is around $40 \mathrm{~m}^{3} / \mathrm{h}$. Before the implementation of the cryogenic technology, the amount of biogas is allocated at $50 \%$ to the boiler $\left(20 \mathrm{~m}^{3} / \mathrm{h}\right)$, for production of heat necessary to the plant, and 50\% (20 $\mathrm{m}^{3} / \mathrm{h}$ ) to a co-generator $(40 \mathrm{kWe})$ for the needed electricity designate to the plant demand and heat to be used to provide the constant project temperature for the two-stage bioreactor reactions $\left(38^{\circ} \mathrm{C}\right)$.

When the criogenetic system will be installed, the amount of gas stream allocated to the upgrading cryogenetic plant will be around $10 \mathrm{~m}^{3} / \mathrm{h}$, and consequently the boiler will work with the use of diesel, and the exhaust gas will be used as accelerant for the algae growing in the pond [7].

The open ponds where macro algae are growing are made from PVC. This allows the control of the cultivation parameters unlike at the open sea. An air stream connected with the ponds will provide water and $\mathrm{CO}_{2}$ (coming from the use of diesel in the plant boiler and from the biogas upgrading step) to the algae broth, thus guaranteeing mixing of the biomass. At the same time eutrophicational agents (partly coming from the biodigestors and partly coming from biowaste - e.g. poultry manure, waste from waste water treatment, other types of biowastes) will be introduced. Summing up all the processes, a closed cycle will be achieved. The cultivation assures strict control of several parameters ( $\mathrm{pH}$, nitrogen compounds, phosphates, etc.) avoiding water exchange with the open sea.

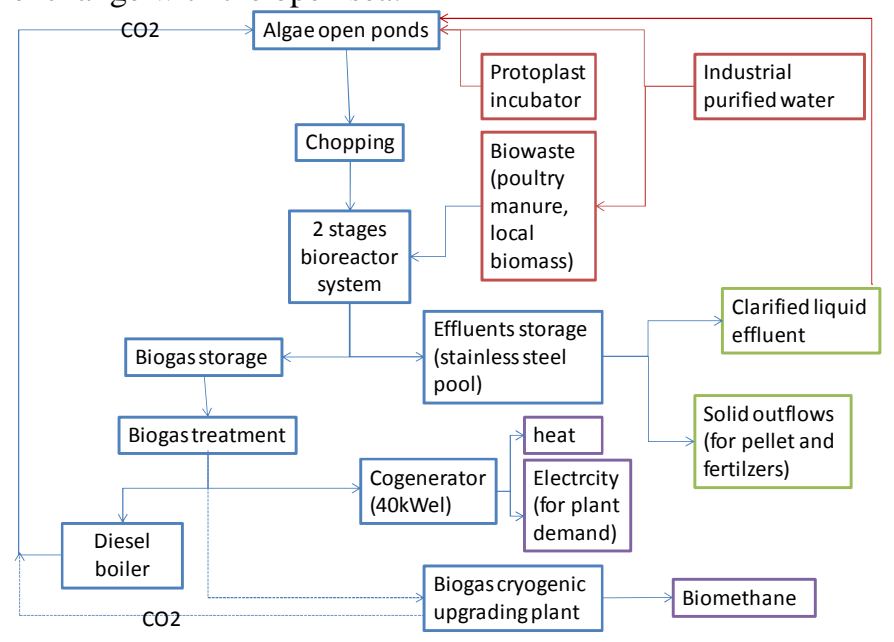

Fig. 2. Scheme of the production system [7]

In reference to the previous scheme the main system inflows are:

- industrial purified water available in situ, to be used directly in the open ponds and to dampen the solid biomass to carry out anaerobic fermentation;

- biowaste to be used for algae growth (e.g. poultry manure) to provide the right amount of nitrogen requested for algae growth;

- insufflated $\mathrm{CO}_{2}$ (together with the right amount of air) gained from the boiler (since starting of macroalgae 
cultivation) and the upgrading plant (from the beginning of the third year);

- clarified effluents from the "Archimede" rotors;

- protoplasts from incubator for production of the initial algal biomass;

- diesel necessary for the heating of the bioreactors and eventually for the open ponds (from project data 140000 $\mathrm{kg}$ /day).

As outflows, with the exception of $\mathrm{CO}_{2}$ already mentioned above, there are:

- heat and electricity from the co-generator $\left(20 \mathrm{~m}^{3} / \mathrm{h}\right.$ since biogas treatment commences);

- residual from the "Archimede" rotors;

- solid fraction to be used for pellets and fertilizers production;

- liquid fraction of residual (clarified effluents) to be reused as input in the algae broth (about $10 \mathrm{~m}^{3} / \mathrm{day}$, after the third year);

- biomethane from the cryogenic upgrading plant $\left(10 \mathrm{~m}^{3} / \mathrm{h}\right.$, after the third year).

\section{LCA: THE BASICS FOR THE MODEL}

In order to identify the environmental "hot spots" of the system and in order to understand and quantify the environmental benefits provided by the plant processes itself, the LCA seems to be one of the best tools, since it provides the possibility to compare several scenarios on the same reference scale (functional unit). In this direction and through the use of cradle-to-grave, the LCA approach will be possible to analyze the following aspects:

- the energy efficiency (ratio of energy in the final fuel to the amount of energy input [14]) and the energy ratio (ratio of energy contained in the final fuel to the energy used by human efforts to produce the fuel in terms of non-renewable energy inputs) associated to the types of plant system used;

- the sustainability of the underlying activities: the longterm feedstock supply should be guaranteed in order to assure long-term biofuel supply to the market depending on sustainability at the local level;

- evaluation of the undesirable emissions of substances to the environment (such as greenhouse gases - GHG).

A cradle-to-grave LCA will be developed following the ISO standards 14040 starting from the supply of the system input, in terms of material (macroalgae, nutrient) and energy, up to the final disposal of the waste, including the re-use of the coproducts.

The production system presented in this paper allows to bypass the high nitrogen content problem of biowaste using macro algae; in fact macro algae represents an optimal interface capable to transform the negative eutrophication potential of such biowaste (related to the high contents of nitrogen and phosphate compounds) in a benefit for algae increasing their growth rate. Moreover, it is important to know that the planet's biomass is for the most part made of algae and hence the use of biomass from an aquatic environment shows a big potential source factor for renewable energy.
Algae need carbon $\mathrm{CO}_{2}$ and nutrients for optimal growth. Increasing the concentration of $\mathrm{CO}_{2}$ in the growth media increase the growth rates by a factor 1.2-1.8 [15, 16, 17, 18].

It appears evident that "eutrophication" as an impact category for the LCA is of primary importance in order to understand the level of environmental benefit provided by the system that will transform negative eutrohpicational impacts (e.g. poultry manure and/or waste from waste water treatment plant and/or other biowaste) into positive ones.

The other impact categories on which to focus attention will be:

- Non-renewable primary energy: in order to evaluate the avoided usage of fossil fuels,

- Climate change: since it is expected that biogas should contribute to the reduction of GHG emissions;

- Acidification: since in the plant removals of $\mathrm{H}_{2} \mathrm{~S}$ occurs.

In the first instance, the LCA scenarios to be compared in the study can be resumed in the following:

- scenario 1: all the biogas produced is demanded for the production of heating (there will a lower consumption of diesel in the boiler but the electricity needed for the plant should be considered );

- scenario 2: all the biogas is used in the co-generator to produce heat and electricity,

- scenario 3: all the biogas is upgraded obtaining liquid biomethane.

In this way the comparison can give the resulting most environmental process, but in this aspect the choice of a correct functional unit is determinant for making the processes comparable.

According to the ISO 14040 norms, the next paragraph will describe the goal and scope of the intended LCA, the system boundaries, the choice of the functional unit and the first aspects for the life cycle inventory.

\section{A. Goal and scope}

The goal of the LCA study will be addressed to evaluate the environmental advantages and disadvantages of the use of macroalage as feedstock for the production of biogas (and after upgrading liquid biomethane) through the identification and quantification of major environmental impacts. It also aims at contributing to the effort of clarifying how marine macroalage potential is an eligible biogas feedstock contributing to the environmental optimization of the growing phase and the conversion processes.

Conclusions of the analysis will be addressed to support decision makers and policymakers.

The intended audience is scientists, stakeholders and policy makers.

\section{B. System boundary}

System boundaries have to be defined iteratively throughout the production system definition and inventory elaboration. Since the object of this study is the production of biogas through the use of macroalagae as feedstock, the system's flow scheme will be centered on the plant processing steps, it will comprise all chemical and technological processes that will ensure the energy flow from its photochemical form to the 
fuel's end use (fig. 3). This means that system boundaries theoretically should include the macroalage cultivation phase, its harvesting and conversion into the fuel and the fuel's consumption and the necessary transportation and the needed new infrastructures of all production stages.

The following picture presents the first model useful for the implementation in a LCA software (e.g. SimaPro® - PRé Consultants, The Netherlands).

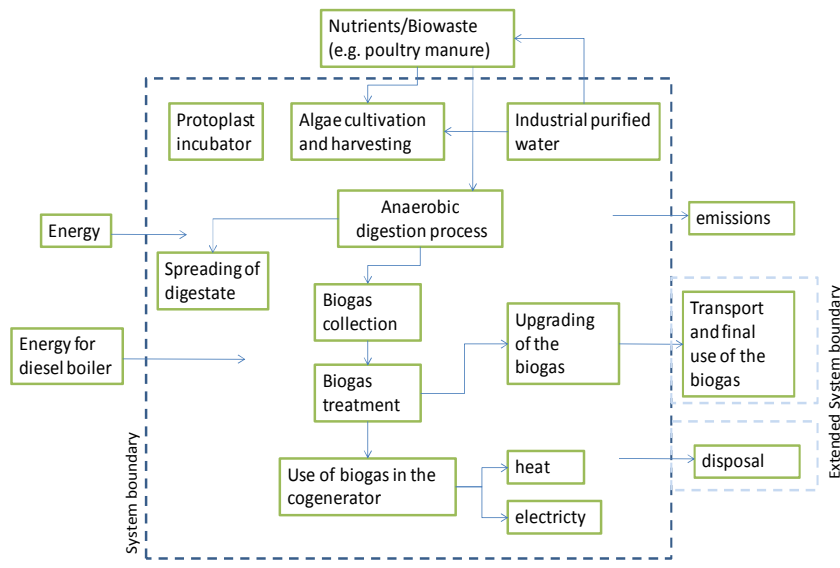

Fig. 3. Overview of the biogas system proposed for the LCA model. The arrows represent the material or energy flows in system.

\section{Functional unit}

This study intends to estimate and quantify the energy balance and environmental impact of the marine macroalgae based on biogas production system.

Depending on its final end use, the adaptation of different functional units can be investigated:

- If transportation is the end use, the adopted functional unit (FU) can be reference to $100 \mathrm{~km}$ driven by a certain type car with liquid gas engine drived on certain types of roads (e.g. local dust roads) fuelled by macroalgae biomethane.

-If production of heat is the final scope of the plant a production of single unit of thermal unit (e.g. 1MWhth) should be used as FU,

-If electricity (in the cogeneration system) is the final use of the plant a production of single unit of electric unit (e.g.

1MWhel) should be considered.

As mentioned in paragraph IV, the correct choice of the functional unit will be essential for making it possible to compare between the different scenarios implemented.

\section{Life cycle inventory}

The following section will present the list of the main data collected up to the present moment. Mainly, the gathered data proceeds from:

- project data,

- literature data,

- data from experts.

Data obtained from published scientific literature are the main sources for input and output modeling. All the data not gathered directly (e.g. transport, land uses, infrastructures processes, etc.) will be implemented from libraries available the LCA software (e.g. SimaPro®).

Table 1 indicates the main data to be considered in the overall impact for a preliminary result.

TABLE I

DATA FOR LCA INVENTORY

\begin{tabular}{|c|c|c|}
\hline Parameter & $\begin{array}{l}\text { Data/Assumption used in } \\
\text { the preliminary LC } \\
\text { inventory }\end{array}$ & Source \\
\hline \multicolumn{3}{|l|}{ Plant project Data } \\
\hline $\begin{array}{l}\text { Theoretical amount of } \\
\text { biogas produced at plant } \\
\text { regime level }\end{array}$ & $40 \mathrm{~m}^{3} / \mathrm{h}$ & [7] \\
\hline Total volume of the pond & $3000 \mathrm{~m}^{3}$ & [7] \\
\hline $\mathrm{CO}_{2}$ from diesel boiler & $1400 \mathrm{~m}^{3} /$ day & [7] \\
\hline $\begin{array}{l}\text { Average monthly water } \\
\text { temperature }\end{array}$ & See figure 5 & {$[7,17]$} \\
\hline $\begin{array}{l}\text { Theoretical minimum algal } \\
\text { daily production }\end{array}$ & $600 \mathrm{~kg}$ (fresh weight) & [7] \\
\hline \multicolumn{3}{|l|}{ Specific algae data } \\
\hline Types of algae used & Ulva prolifera & - \\
\hline Algae cultivation duration & 10 days & - \\
\hline $\begin{array}{l}\text { Algae daily growth rate } \\
\text { (DGR), natural condition }\end{array}$ & $\begin{array}{l}\text { Variable with temperature } \\
\text { (see figure 5) }\end{array}$ & [19] \\
\hline $\begin{array}{l}\text { Increase of the DGR due to } \\
\text { nutrient and } \mathrm{CO} 2\end{array}$ & $\begin{array}{l}\text { Ulva lactuca: } 20 \% \text { Ulva } \\
\text { prolifera: } 45 \%\end{array}$ & {$[7,16]$} \\
\hline $\begin{array}{l}\text { Increase of the RGR due to } \\
\text { light }\end{array}$ & Not consider at this stage & \\
\hline $\begin{array}{l}\text { Dissolved Organic } \\
\text { Compounds (DOP) and } \\
\text { Particulated Organic } \\
\text { Compounds (POC) }\end{array}$ & $\% \mathrm{C}=5 \%$ of the dry weight & {$[18]$} \\
\hline $\begin{array}{l}\text { Amount of } \mathrm{CO}_{2} \text { in solution } \\
\text { in water }\end{array}$ & $\begin{array}{l}\text { equal to the same present in } \\
\text { the normal has been choosen: } \\
\text { a value of } 0.09 \mathrm{~g} / 1(=0.09 \\
\left.\mathrm{kg} / \mathrm{m}^{3}\right)\end{array}$ & {$[20]$} \\
\hline $\begin{array}{l}\text { Amount of } \mathrm{CO}_{2} \text { absorbed } \\
\text { for the algal biomass } \\
\text { growing }\end{array}$ & $\begin{array}{l}\text { starting assumption: } \\
\text { percentage of the Carbon } \\
\text { contained in the algal } \\
\text { biomass equal to } 30 \%\end{array}$ & [21] \\
\hline $\begin{array}{l}\mathrm{CO}_{2} \text { per unit of bubble air } \\
\text { rate flow }\end{array}$ & $1500 \mu \mathrm{l} / 1_{\text {air }}$ & {$[18]$} \\
\hline $\begin{array}{l}\text { Daily algae extraction } \\
\text { working hour }\end{array}$ & 12 hours & \\
\hline \multicolumn{3}{|l|}{ Specific technical data } \\
\hline $\begin{array}{l}\text { Amount of nutrient for } \\
\text { macroalage growth (e.g. } \\
\text { poultry manure) }\end{array}$ & See table III & \\
\hline Percentage of dry mass & $20 \%$ & {$[16]$} \\
\hline $\begin{array}{l}\text { Percentage of volatile } \\
\text { solids (VS) }\end{array}$ & See table II & \\
\hline Theoretical biogas yield & 275 1/kg $\mathrm{ks}^{*}$ (Ulva Prolifera) & {$[16]$} \\
\hline Low biogas heating value & $23.3 \mathrm{MJ} / \mathrm{m}^{3}$ & {$[22]$} \\
\hline
\end{tabular}

All the previous data and assumptions used for the preliminary calculations will be better described in the next paragraph. The data referred to the algae species reported in Table II is the result of a literature review in collaboration 
with the National Environmental Research Institute of Aarhus University (NERI) [16]

Table 2 with the relative literature references shows that the foreseeable biogas production yield from a certain type of algae is rather wide depending on several factors (type of algae, local environmental condition, temperature, salinity, $\mathrm{pH}$, hours of daily light, and type of nutrients received).

TABLE II

DATA FOR POSSIBLE ALGAE SPECIES TO BE USED IN THE PLANT

\begin{tabular}{|c|c|c|c|c|}
\hline & Ulva lactuca & $\begin{array}{l}\text { Ulva } \\
\text { prolife } \\
\text { ra }\end{array}$ & $\begin{array}{l}\text { C. } \\
\text { linum }\end{array}$ & Gracilaria \\
\hline $\begin{array}{l}\text { Volatile } \\
\text { solids } \\
\text { (\%d.wt) }\end{array}$ & $\begin{array}{l}79-87[25] \\
65-83[27] \\
65[28] \\
70-72[26]\end{array}$ & - & - & $52-65[26]$ \\
\hline $\begin{array}{l}\text { Yearly } \\
\text { yield }(t \\
\text { d.wt/ha/y) }\end{array}$ & 45 [29] & - & - & $40-127$ [30] \\
\hline $\begin{array}{l}\text { Maximum } \\
\text { seasonal } \\
\text { yield }\end{array}$ & - & - & - & \\
\hline $\begin{array}{l}\text { Biogas yield } \\
(\mathrm{ml} / \mathrm{g} \text { VS) }\end{array}$ & $\begin{array}{l}280[29] \\
94-177 \mathrm{CCH}_{4} / \mathrm{kg}_{\mathrm{VS}}[30] \\
77-560[26]\end{array}$ & $\begin{array}{l}275 \\
1 / \mathrm{kg}_{\mathrm{VS}} \\
{[18]}\end{array}$ & $\begin{array}{l}125 \\
{[29]}\end{array}$ & $\begin{array}{l}83-430[26] \\
540[30]\end{array}$ \\
\hline
\end{tabular}

\section{V.ALGAE GROWING: CONSIDERATION AND RESULTS OF} PARAMETERS THAT AFFECTS THE BIOGAS YIELD

At the moment, the first step for the Life cycle inventory has been addressed to the growing phase of the macroalage in open ponds in order to carry out the data regarding the biogas production yield.

One of parameter that affects the production yield of biogas is the total production of algal biomass that the cultivation can provide. In this light, it is fundamental to know the daily growth rate of the algal specie. The daily growth rate (DGR) represents the growing rate as a percentage. This can be calculated from the resulting increase in the algal biomass in fresh weight and is expressed as percentage of growth per day, The formula is expressed as follows [19]:

$$
\mathrm{DGR}=\left[(\mathrm{Wt} / \mathrm{Wo})^{1 / \mathrm{t}}-1\right] \times 100
$$

where:

- DGR (daily growth rate) is the daily growth rate in fresh weight per day,

- Wo is initial weight,

- Wt is weight after t days.

The algae growing phase is dependent on the temperature of water of the growing medium $[18,19,21]$ and consequently, the seasonal variation of temperature can affect the global biomass production yield.
As explained before, the main principle of the plant process is to use nutrients from waste for algae growing (e.g. wastewater from wastewater treatment plant, and poultry manure from local animal farm) and at the same time reused $\mathrm{CO}_{2}$ from the plant processes (from the diesel boiler and the biogas upgrading) in order to accelerate the growing process and avoid negative environmental impacts.

It is consequently fundamental to know the amount of the inlet $\mathrm{CO}_{2}\left(\mathrm{CO}_{2 \text { in }}\right)$ responsible for the algae biomass growing $\left(\mathrm{CO}_{2 \mathrm{BM}}\right)$, the solution in the water $\left(\mathrm{CO}_{2 \text { wat }}\right)$, the releases in the atmosphere from the surface of the open ponds $\left(\mathrm{CO}_{2 \mathrm{rel}}\right)$, and dissolved organic carbon and particulate organic carbon biomass $\left(\mathrm{CO}_{2 \text { D.P. }}\right)$.

All these parameters can be summarized in the following equation that expresses the mass equivalence of inlet $\mathrm{CO}_{2}$ :

$$
\mathrm{CO}_{2 \text { in }}=\mathrm{CO}_{2 \text { rel }}+\mathrm{CO}_{2 \mathrm{BM}}+\left(\mathrm{CO}_{2 \text { D.P. }}\right)+\mathrm{CO}_{2 \text { wat }}
$$

In this equation

$\mathrm{CO}_{2 \text { in }}=$ inlet $\mathrm{CO}_{2}$ in the open ponds $=1400 \mathrm{~kg} / \mathrm{day}$,

$\mathrm{CO}_{2 \text { rel }}=$ part of the $\mathrm{CO}_{2}$ that leaves the open ponds,

$\mathrm{CO}_{2 \mathrm{BM}}=$ part of the $\mathrm{CO}_{2}$ responsible for the algae biomass growing,

$\mathrm{CO}_{2 \text { wat }}=\mathrm{CO}_{2}$ in solution,

$\mathrm{CO}_{2 \text { D.P. }}=\mathrm{CO}_{2 \mathrm{DOC}}+\mathrm{CO}_{2 \text { POC }}$,

Where:

DOC $=$ dissolved organic carbon,

$\mathrm{POC}=$ particulate organic carbon.

Figure 4 better visualizes the equation 2 .

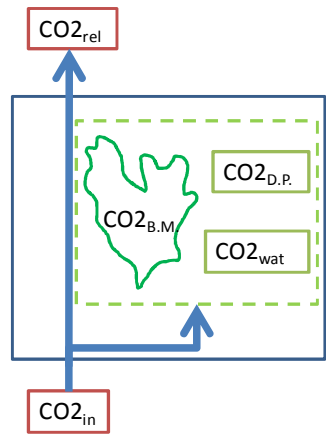

Fig. 4. Scheme used for the calculation of the model used for the $\mathrm{CO}_{2}$ mass balance.

The amount of $\mathrm{CO}_{2}$ daily provided to the open ponds $\left(\mathrm{CO}_{2 \text { in }}\right)$ is known from the project initial data and is equal to $1400 \mathrm{~kg} /$ day.

The amount of $\mathrm{CO}_{2}$ transformed in algae filamentous biomass $\left(\mathrm{CO}_{2 \mathrm{BM}}\right)$ can be calculated in this way: once the amount of algae biomass produced is known (in accordance with the DGR chosen) and the percentage of the carbon contained in the algal biomass is also known (in first instance equal to $30 \%$ of the dry weight [21]) is possible to know the amount of $\mathrm{CO}_{2}$ by a simple proportion between the two molecular weight (it is assumed that all the Carbon in the $\mathrm{CO}_{2}$ is responsible for the creation of the algal carbon content) and 
after multiplying with the carbon content in the dry weight of the algal biomass:

$$
\mathrm{CO}_{2 \mathrm{BM}}[\mathrm{kg}]=\text { Biomass Dry Weight }[\mathrm{kg}] \text { x \% } \mathrm{C} \text { 44/12 }
$$

In this formula, the Biomass Dry weight is assumed equal to $20 \%$ of the total algal biomass $[16,29]$.

The amount of $\mathrm{CO}_{2}$ that goes in solution needs to be studied in more detail, at the moment the assumption to assign to the outlet water a value of $\mathrm{CO}_{2}$ equal to the same typically present in the seawater $\left(0.09 \mathrm{~g}_{\mathrm{CO} 2} / 1\right.$ [20]) has been chosen. If the total hourly water recirculation rate is known together with the working hours of the system, it is possible to evaluate the parameter $\mathrm{CO}_{2 \text { wat }}$. The final calculation is described below:

$$
\mathrm{CO}_{2 \text { wat }}=\mathrm{CO}_{2 \text {, seawater }} \times \mathrm{q} \times \mathrm{h}_{\text {work }}=16.2 \mathrm{~kg} / \text { day }
$$

Where:

$\mathrm{CO}_{2 \text { wat }}=\mathrm{CO}_{2}$ in solution in the open ponds $=16.2 \mathrm{~kg} / \mathrm{day}$;

$\mathrm{CO}_{2}$, seawater $=\mathrm{CO}_{2}$ content in the sea water $=0.09 \mathrm{~kg} / \mathrm{m}^{3}$,

$\mathrm{q}=$ hourly water recirculation $=15.0 \mathrm{~m}^{3} / \mathrm{h}$,

$\mathrm{h}_{\mathrm{work}}=$ daily working hours $=12 \mathrm{~h} /$ day.

During the growing phase a portion of the algae biomass body is lost. This part could be not directly detected from the weighting of the fresh weight of the harvested mass. This is exactly the part of the dissolved organic carbon (DOC) and particulate organic compounds (POC). Regarding this amount from literature review [18] a total value equal to $5 \%$ of the dry weight is assigned.

The last factor of the $\mathrm{CO}_{2}$ release out of the open pond is calculated by equation 1 only subtracting all the other amounts of $\mathrm{CO}_{2}$ previously calculated.

After the description of the basic model for the calculation of the absorption $\mathrm{CO}_{2}$ process in the open ponds, some conclusions can be carried out for the final production of biogas in particularly regarding the macroalgae Ulva Prolifera. This is better described in the next paragraph.

The pilot project foresees the possibility to optimize the choice of the best suitable algae for the production of biogas in terms of lower environmental impact and local sustainability. This step is still under development, nevertheless, the following paragraphs report the results of the preliminary studies and calculation for the production of biogas for a feedstock of Ulva Prolifera using a certain type of characterized nutrient (poultry manure).

\section{FIRST LIFE CYCLE INVENTORY ANALYSIS RESULTS}

As first result of the Life Cycle Inventory in this paragraph the calculation of the final production of biogas from the use of the macroalgae Ulva Prolifera is presented. In these first calculations, the following has been considered: a certain classification of the poultry manure use a nutrient [30], a fixed nutrient uptake level for the algae [see table III], a variation of the DGR [21] depending on sea surface temperature based on monthly average temperature on-site (Augusta, Italy) [17], and an increase of DGR due to adding of $\mathrm{CO}_{2}$ [16]. Part of the final biogas production is provided from the digestion of the algal biomass and part directly from the digestion of the poultry manure itself.

In the following section the input parameters necessary for the calculations are better described.

\section{A. Poultry manure}

The choice of feedstock to be used as nutrients for algae and as medium responsible for the production of biogas through anaerobic digestion has been addressed to poultry manure. In the first instance this has been consider a sustainable substance present on site.

Since the nitrogen form that preferentially is absorbed by the mentioned algae specie is ammonium $\left(\mathrm{NH}_{4}^{+}\right)$or nitrate $\left(\mathrm{NO}_{\mathrm{x}}\right)$ the work has been focused to characterizing these substances addressing the attention on the ratio $\mathrm{NH}_{4}{ }^{+} / \mathrm{NO}_{\mathrm{x}}$ and $\mathrm{NH}_{4}{ }^{+} / \mathrm{N}$ tot $[30,31,32,33,34]$.

At this step of the modelling, it has been decided to adopt the following values [30] that were representative for almost all the data analyzed during the literature review.

$$
\begin{aligned}
& \frac{N H_{4}^{+}}{N O x}=56.7 \\
& \frac{N H_{4}^{+}}{N t o t}=0.5
\end{aligned}
$$

The relative amount of $\mathrm{NH}_{4}{ }^{+}, \mathrm{NO}_{\mathrm{x}}$ and $\mathrm{N}_{\text {tot }}$ can be easily derived:

$$
\begin{aligned}
& \mathrm{NH}_{4}^{+}=6.35 \mathrm{~g} / \mathrm{kg} ; \\
& \mathrm{NO}_{\mathrm{x}}=0.112 ; \\
& \mathrm{N}_{\text {tot }}=12.7 \mathrm{~g} / \mathrm{kg} .
\end{aligned}
$$

\section{B. Algae absorption capacity}

This parameter depends mainly from the type of algae used.

For the calculations, the values reported in the following Table 3 derived by NERI own data have been adopted.

TABLE III

NUTRIENT UPTAKE LEVEL FOR ULVA PROLIFERA

\begin{tabular}{|l|l|}
\hline Uptake Phosphate: & $25 \mathrm{mg} / \mathrm{gd} . w \mathrm{t} / \mathrm{d}$ \\
\hline Uptake Nitrate: & $20 \mathrm{mg} / \mathrm{gd} . w \mathrm{t} / \mathrm{d}$ \\
\hline Uptake Ammonium: & $100 \mathrm{mg} / \mathrm{gd} . \mathrm{wt} / \mathrm{d}$ \\
\hline
\end{tabular}

The dry weight (d.wt) presents a variable value, NERI suggested values between 14 and $20 \%$ of the fresh of algae [17] in our calculation we used a value equal to $20 \%$.

Since not all the polluting components of the entire amount of feed-in poultry manure are up-taken from the alga, particularly attention should be further paid to the collecting re-use and/or disposal of these environmentally dangerous substances.

C. DGR depending on sea temperature based on monthly average temperature on-site (Augusta Italy) 
Figure 5 shows the variation of the mean temperature of the surface sea water on the plant site in Augusta which affects the DGR. The temperatures data have been directly provided from the owner of the plant site: the company Ecoil [17].

The formula used for calculation of the DGR depending on temperature rate is shown below [18].

$$
\text { DGR }=-0.234 \mathrm{~T}^{2}+10.134 \mathrm{~T}-64.647
$$

Where $\mathrm{T}$ is the temperature of the growing medium.

Figure 5 indicates the variation of the algae DGR in natural condition and the increase due to the use of growing medium rich in $\mathrm{CO}_{2}$ together with the seasonal sea surface temperature variation. Between May and November the DGR shows steady behaviour.

\section{Air needed for the open ponds system}

Based on literature data [20], a value of $1500 \mu \mathrm{CO}_{2}$ per lt of air insufflate in the open pond has been assumed (see Table I). Since $1400 \mathrm{kgCO}_{2} /$ day has been assumed to feed the open pond, and using the previously mentioned share of $\mathrm{CO}_{2}$ concentration per liter of insufflated air, a total amount of $54000 \mathrm{~m}^{3} / \mathrm{h}$ is consequently needed. In terms of the LCA, the energetic load of this factor should be taken into account.

\section{E. Water needed to replace the daily harvesting of algae}

If the rate of insufflate air in the open ponds is constant, the water to supply in order to have a steady total mass in the open ponds is variable. The volume of the water that daily has to be let out is equal to the daily increase of the algae volume. As it was mentioned before, the growth of the algae depends on several factors with the consequence to constitute a variable parameter.

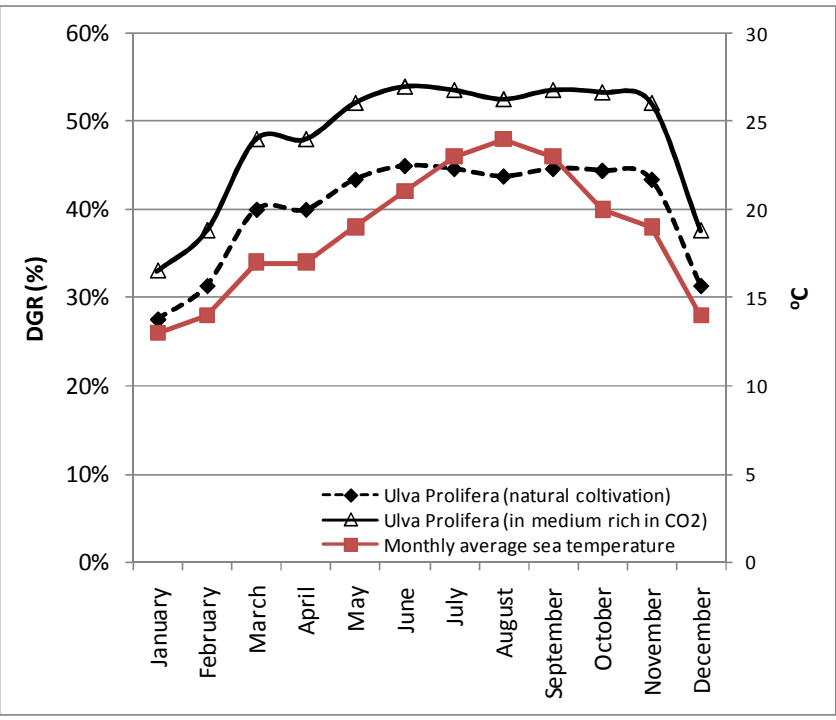

Fig. 5. Variation of the DGR for Alga Prolifera in reference to the surface sea temperature. For the DGR variation has been used the formulation of Hiraoka - Oka (2008) [21]. The second axis presents the seasonal variation of the temperature of the sea surface.

\section{F. Production of biogas}

In the following section, the main results for the production of biogas and biomethane are shown with the following assumptions:

- initial algal mass: $100 \mathrm{~kg}$ (algal protoplast),

- duration of cultivation: 10 days (necessary to guarantee the minimum level of produced algal biomass per day, see Table I);

- $\mathrm{CO}_{2 \text { in }}: 1400 \mathrm{~kg} / \mathrm{day}$;

- Water recirculation: $15 \mathrm{~m}^{3} / \mathrm{h}$;

- Algae dry weight $=20 \%$ freshweight;

- DGR increase due to medium rich in $\mathrm{CO}_{2}$ respect the natural DGR: $20 \%$;

- \%C fixed in algae: $30 \%$;

- Use of poultry manure as nutrient: see table III for the characteristics;

- Volatile solids: 78\%d.wt (from Table II),

- $\mathrm{CH}_{4}$ yield: 350 1/ $\mathrm{kg}_{\mathrm{vs}}$ (from Table II).

- Contain of $\mathrm{CH}_{4}$ in the biogas mix: $60 \%$ (from table I),

- Concentration of $\mathrm{CO}_{2}$ in the outlet water $0.09 \mathrm{~g} / \mathrm{l}$ (see Table II)

- Production yield $\mathrm{CH}_{4}$ only from the poultry manure: $44.5 \mathrm{~m}^{3} /$ ton (conservative factor equal to 0.8 ) [29]

- Half of the nutrients re-circulate in the system after the digestion (factor 0.5 for the calculation of the daily amount of poultry manure).

As one can see, between May and November all the $\mathrm{CO}_{2}$ inlet in the open ponds is theoretically fixed by the algae, thus resulting in a null level of $\mathrm{CO}_{2 \text { rel }}$ in the atmosphere.

The yearly production of biogas is around $157000 \mathrm{~m}^{3} /$ year where the share of $\mathrm{CH}_{4}$ is around $60 \%$. The average hourly production is around $38 \mathrm{~m}^{3} / \mathrm{h}$, which is in line with what was decrypted in the preliminary plant technical data $\left(40 \mathrm{~m}^{3} / \mathrm{h}\right)$.

A more detailed analyses should be carried out in order to understand if the proposed algae will be the best solution for the local condition in Augusta. Further information is also essential to characterize and choose the real feedstock to be used as nutrient for algae.

In terms of a cradle to grave LCA, as described before, it is a really good starting point but further unit processes should be analyzed taking into account several other system steps like:

- energy and emissions necessary for the production of materials and parts needed for the operation of the biogas plant in all its portions;

- energy and the emissions for all the transportation;

- evaluation of the impact of cultivation of protoplast to be transfer in the open ponds;

- final waste disposal scenario.

From data received from NERI the best suitable lighting scenario for algae growing should be at least equal to 12 hours of light per day. This situation can be only guarantied in situ with artificial light. Nevertheless despite more hours per day of light an increase of DGR will be gained. In this regard further analysis should be assessed evaluating how much 
energy is required for the lightning system and how much is the benefit in terms of the amount of gas produced.

The following paragraph reports some considerations regarding the adaptation of the production of biogas to Latvian conditions with the same previous assumptions. This is merely a theoretical approach that takes into account a minimum temperature of $10^{\circ} \mathrm{C}$ in the open ponds (otherwise equation 4 results in a negative value). Of course this condition should be guaranteed only with external thermal energy requirements that decrease the level of renewability of the process and increase the level of environmental impact.

TABLE IV

PRODUCTION OF BIOGAS IN THE PLANT BASED ON MONTHLY AVERAGE SEE TEMPERATURE USING ULVA PROLIFERA

\begin{tabular}{|c|c|c|c|c|c|c|c|}
\hline & $\mathrm{CO}_{2 \mathrm{rel}}$ & $\mathrm{CO}_{2 \mathrm{abs}}^{*}$ & $\begin{array}{l}\text { Poultry } \\
\text { mamure }\end{array}$ & $\begin{array}{l}\mathrm{CH}_{4} \text { from } \\
\text { algae }\end{array}$ & $\begin{array}{l}\mathrm{CH}_{4} \text { from } \\
\text { poultry } \\
\text { manure }\end{array}$ & $\mathrm{CH}_{4}$ tot. & Biogas total \\
\hline Month & $\mathrm{t} / \mathrm{month}$ & $\mathrm{t} / \mathrm{month}$ & $\mathrm{t} / \mathrm{month}$ & $\mathrm{m}^{3} / \mathrm{month}$ & $\mathrm{m}^{3} / \mathrm{month}$ & $\mathrm{m}^{3} /$ month & $\mathrm{m}^{3} / \mathrm{month}$ \\
\hline January & 19 & 9 & 25 & 1493 & 539 & 2031 & 3386 \\
\hline February & 21 & 17 & 49 & 2826 & 1038 & 3864 & 6440 \\
\hline March & 3 & 39 & 114 & 6492 & 2437 & 8929 & 14882 \\
\hline April & 3 & 37 & 110 & 6276 & 2356 & 8631 & 14386 \\
\hline May & 0 & 42 & 124 & 7067 & 2658 & 9725 & 16208 \\
\hline June & 0 & 42 & 124 & 7067 & 2658 & 9725 & 16208 \\
\hline July & 0 & 42 & 124 & 7067 & 2658 & 9725 & 16208 \\
\hline August & 0 & 42 & 124 & 7067 & 2658 & 9725 & 16208 \\
\hline September & 0 & 41 & 120 & 6832 & 2569 & 9401 & 15668 \\
\hline October & 0 & 43 & 129 & 7303 & 2746 & 10049 & 16749 \\
\hline November & 0 & 42 & 124 & 7067 & 2658 & 9725 & 16208 \\
\hline December & 16 & 12 & 36 & 2093 & 769 & 2862 & 4771 \\
\hline & \multicolumn{5}{|c|}{$* \mathrm{CO}_{2 \mathrm{abs}}=\mathrm{CO} 2_{\text {B.M. }}+\mathrm{CO} 2_{\text {D.P. }}+\mathrm{CO}_{2 \text { wat }}$} & $\begin{array}{l}\text { TOT. } \\
\text { (1 year) }\end{array}$ & 157323 \\
\hline
\end{tabular}

TABLE V

AVOIDED IMPACT

\begin{tabular}{|c|c|c|c|c|c|c|c|}
\hline & $\begin{array}{l}\text { Heat (from } \\
\text { cogenration) }\end{array}$ & $\begin{array}{l}\text { avoided kg } \\
\text { of diesel }\end{array}$ & $\begin{array}{l}\text { avoided } \mathrm{CO}_{2} \\
\text { (from use of } \\
\text { diesel) }\end{array}$ & $\begin{array}{l}\text { Electricity } \\
\text { (from } \\
\text { cogeneration) }\end{array}$ & $\begin{array}{l}\text { avoided } \mathrm{CO}_{2} \\
\text { (from electrical } \\
\text { energy) }\end{array}$ & $\begin{array}{l}\text { Total } \\
\text { avoided } \mathrm{CO}_{2}\end{array}$ & $\begin{array}{l}\text { Total } \mathrm{CO}_{2} \text { balance } \\
\text { including } \mathrm{CO}_{2 \mathrm{rel}}^{*}\end{array}$ \\
\hline Month & MJth & ton & ton & MJel & ton & ton & ton \\
\hline January & 47330 & 1,1 & 3,5 & 27609 & 4,4 & 8,0 & 11,3 \\
\hline February & 90038 & 2,1 & 6,7 & 52522 & 8,5 & 15,2 & 6,0 \\
\hline March & 208046 & 4,9 & 15,5 & 121360 & 19,6 & 35,1 & $-31,6$ \\
\hline April & 201111 & 4,7 & 15,0 & 117315 & 18,9 & 33,9 & $-30,6$ \\
\hline May & 226593 & 5,3 & 16,9 & 132179 & 21,3 & 38,2 & $-38,2$ \\
\hline June & 226593 & 5,3 & 16,9 & 132179 & 21,3 & 38,2 & $-38,2$ \\
\hline July & 226593 & 5,3 & 16,9 & 132179 & 21,3 & 38,2 & $-38,2$ \\
\hline August & 226593 & 5,3 & 16,9 & 132179 & 21,3 & 38,2 & $-38,2$ \\
\hline September & 219040 & 5,1 & 16,3 & 127773 & 20,6 & 36,9 & $-36,9$ \\
\hline October & 234146 & 5,5 & 17,4 & 136585 & 22,0 & 39,4 & $-39,4$ \\
\hline November & 226593 & 5,3 & 16,9 & 132179 & 21,3 & 38,2 & $-38,2$ \\
\hline December & 66695 & 1,6 & 5,0 & 38905 & 6,3 & 11,2 & 4,4 \\
\hline & \multicolumn{5}{|c|}{ *a negative sign means theoretical displaced $\mathrm{CO}_{2}$ from the atmosphere } & $\begin{array}{l}\text { TOT. } \\
\text { (1 year) }\end{array}$ & $-307,7$ \\
\hline
\end{tabular}




\section{AVOIDED IMPACT}

This paragraph describes the avoided impact using the yearly production of biogas only for the scenario where it is assumed that all the biogas is used to supply the $40 \mathrm{~kW}$ cogeneration system.

The results are summarized in the Table $\mathrm{V}$ and have taken into account the following assumptions:

- Cogeneration efficiency for the production of thermal energy: $60 \%$;

- Cogeneration efficiency for the production of electrical energy: $35 \%$;

- Daily working load of the cogeneration system: 12 hours/day;

- Low heating value diesel: $42.6 \mathrm{MJ} / \mathrm{kg}$ [35];

- Low heating value of the biogas: $23.3 \mathrm{MJ} / \mathrm{m}^{3}$ [36],

- $\mathrm{CO}_{2}$ diesel emission factor: $74.5 \mathrm{~g} / \mathrm{MJ}$ [22],

- $\mathrm{CO}_{2}$ emission factor, with reference to the Italian electricity mix production $=0,58 \mathrm{~kg} \mathrm{CO} / \mathrm{kWh}_{\mathrm{el}}$ [7].

As one can see there is a total reduction of $\mathrm{CO}_{2}$ emission equal to $308 \mathrm{t} /$ year.

\section{A. Avoided impact for Latvian conditions}

The same calculations have been carried out for Latvian conditions using the monthly average temperature of the sea surface in the Gulf of Riga [36] and the emission factors of $0.181 \mathrm{~kg} / \mathrm{MWh}_{\mathrm{el}}$ [37]. The production of biogas in this case equals $49800 \mathrm{~m}^{3} /$ year but in this condition considering a minimum temperature in the ponds equal to $10^{\circ} \mathrm{C}$ (with a consequence big amount of thermal energy spend for heating) the results show that the $\mathrm{CO}_{2}$ net balance is positive with the consequence that $\mathrm{CO}_{2}$ release in atmosphere is greater than that absorbed. Further investigations are necessary to understand if this novel technology is exploitable also for Latvian conditions. Under the same assumptions used for the calculations on the plant sit in Italy, at the moment a good production of biogas, using such kind of novel technology is possible only between May and October.

\section{VIII.CONCLUSIONS}

This paper has presented the example of a biogas plant included in the pilot project biowalk4biofuels [12] devoted to the production of biogas using macro algae as feedstock and poultry manure (or other biowastes rich in nitrogen and phosphate) as inoculum for algae growing and for the biodigesters. The paper describes the first aspects concerning the establishment of a LCA system model. The base flow chart needed for the model, the choice of the possible functional units and the main impact categories to be investigated, the first calculations regarding the amount of algae produced in the system in correlation to the final expected biogas production, and the base for the LCA inventory has been carried out. Some preliminary aspects in terms of avoided impact from $\mathrm{CO}_{2}$ are also described in this paper together with considerations regarding the possibility to implement this technology in Latvian conditions.
The results, under the assumptions mentioned in the paper shows that the total amount of biogas produced per year, in the pilot plant in Augusta, is approximately equal to 157000 $\mathrm{m}^{3} /$ year with a saving of $\mathrm{CO}_{2}$ emissions equal to $308 \mathrm{t} /$ year for the scenario where it is assumed that all the biogas is used to supply the $40 \mathrm{~kW}$ cogeneration system.

In terms of eutrophicational benefits, the results show that the plant system can dispose around 1200 tons of poultry manure per year.

The calculations carried out for Latvian conditions shows a yearly production of biogas equal to $49800 \mathrm{~m}^{3} /$ year considering a minimum temperature in the ponds equal to $10^{\circ} \mathrm{C}$. The results show that the $\mathrm{CO}_{2}$ net balance is positive with the consequence that $\mathrm{CO}_{2}$ release in atmosphere is greater than that absorbed. Under the same assumptions used for the calculations on the plant sit in Italy, at the moment a good production of biogas, using such kind of technology is possible only between May and October.

In light of the final goals in connection with the biowal4biofuels project the paper highlights the importance to:

- develop and strengthen the know-how in algae cultivation and research, as well as the interest of the industrial field, with the concrete possibility to set-up spin-offs or to stimulate private investors by furnishing a clear socioeconomical and normative framework useful to enhance the competitiveness of European industry;

- local reduction of nitrogen and phosphates which have seriously degraded the aquatic ecosystems through the use of local biowaste;

- renewable biogas from waste;

- contribution to a progress in a profitable way of remediating the nutrient pollution from fish farms, agriculture, industry etc.;

- delivering raw material for $\mathrm{CO}_{2}$ neutral bioenergy;

- provide a good evaluation tool for private investors, stakeholders and policy makers.

\section{ACKNOWLEDGMENTS}

The research leading to these results has received funding from the European Community's Seventh Framework Programme FP7/2007-2013 under grant agreement n²41383 in reference to the project Biowalk4biofuels.

\section{REFERENCES}

1. Directive $2009 / 28 / \mathrm{EC}$, on the promotion of the use of energy from renewable sources and amending and subsequently repealing Directives 2001/77/EC and 2003/30/EC http://eurlex.europa.eu/LexUriServ/LexUriServ.do?uri=OJ:L:2009:140:0016:00 62:en:PDF

2. Directive $2007 / 71 / \mathrm{EC}$, on the promotion of electricity produced from renewable energy sources in the internal electricity market http://www.erec.org/fileadmin/erec_docs/Projcet_Documents/RES2020 /LATVIA_RES_Policy_Review_09_Final.pdf.

3. Council Directive 1999/31/EC of 26 April 1999 on the landfill of waste. http://eurex.europa.eu/LexUriServ/LexUriServ.do?uri=CELEX:31999L0031:EN :NOT

4. Council Directive of 12 December 1991 concerning the protection of waters against pollution caused by nitrates from agricultural sources 
$(91 / 676 / \mathrm{EEC})$ nitrates/directiv.htm

http://ec.europa.eu/environment/water/water-

5. FAO - Food and Agriculture Organization, 2008. The State of Food and Agriculture. Biofuels: prospects, risks and opportunities. Rome, Italy.

6. Von Blottnitz H. A review of assessments conducted on bio-ethanol as a transportation fuel from a net energy, greenhouse gas, and environmental life-cycle perspective. Accepted for Publication in the Journal of Cleaner Production, March 1, 2006.

7. Biowaste and algae knowledge for the production of $2^{\text {nd }}$ generation biofuels (BioWALK4Biofuels). Annex I - "Description of Work". Grant agreement no.: 241383, April 2010, Rome. www.biowlak4biofuel.ue

8. Putt R. Algae as a Biodiesel Feedstock: A Feasibility Assessment Center for Microfibrous Materials Manufacturing (CM3) - Department of Chemical Engineering. Auburn University, Alabama, USA, November 20, 2007.

9. Walter M., Kondrad S., Buyer J. Treatment of dairy and swine manure effluents using freshwater algae: fatty acid content and composition of algal biomass at different manure loading rates. Journal of of Applied Phycology, 2008, N. 20, pp.1079-1085.

10. Nallathambi Gunaseelan V. Anaerobic digestion of biomass for methane production: A review. Biomass and Bioenergy, Vol. 13, Issues 1-2, 1997, pp. 83-114.

11. De Mes T.Z.D., Stams A.J.M., Reith J.H., Zeeman G. Methane production by anaerobic digestion of wastewater and solid wastes. Biomethane \& Bio-hydrogen. Edited by: J.H. Reith, R.H. Wijffels and H. Barten Dutch Biological Hydrogen Foundation, 2003.

12. Reddy C.R.K., Gupta M.K., Mantri V.A., Jha B. Seaweed protoplasts: status, biotechnological perspectives and needs. Applied Phycology Journal, 2008, Vol. 20, N. 5, October, pp. 619-632.

13. Wenisch S., Monier E. Life Cycle Assessment of different of biogas from anaerobic fermentation of separately collected biodegradable waste in France. ADEME - French Agency for the Environment and Energy Management, 2007, France.

14. Njakou Djomo S. PhD. Life Cycle Assessment of Biohy ${ }^{\mathrm{dr}}$ ogen production and applications for modeling the transition to hydrogen economy, $\mathrm{PhD}$ thesis, 2009, Riga, $149 \mathrm{p}$.

15. Bidwell RGS, McLachlan J and Lloyd, NDH. Tank cultivation of Irish Moss, Chondrus crispus Stackh. Botanica Marina, 1985. N. 2828:, pp. 87-97.

16. Courtesy of own data from National Environmental Research Institute, Aarhus University, 2010. Nordre Ringgade, 8000, AARHUS Denmark, www.au.dk.

17. Courtesy of own data from Ecoil srl, Roma, 2010, via Adolfo Ravà, 49, 00142 Roma, www.ecoil.biz.

18. Gordillo F.J.L., F., Xavier Niell F., Figueroa F.L. Non photosintetic enhancement of growth by high CO2 level in the nitrophilic seaweed Ulva rigida C. Agardh (Chlorophyta), Planta, 2001, N. 213, pp. 64-70.

19. Hiraoka M., Oka N. Tank cultivation of Ulva prolifera in deep seawater using a new "germling cluster" method, Journal of Applied Phycology, 2008 , N. 20, pp. $97-102$

20. The chemical composition of seawater, http://www.seafriends.org.nz/oceano/seawater.htm\#gases

21. Michalak I., Chojnacka K. Edible macroalga Ulva prolifera as microelemental feed supplement for livestock: the fundamental assumptions of the production method. World Journal of Microbiolology and Biotechnology, 2009, N. 25, pp. 997-1005.

22. Global emission model for integrated systems, LCA software and database version 4.5 (GEMIS 4.5) : diesel-DE-2005

23. De Padua M., Fontoura P.S.G., and Mathias A.L. 2004. Chemical composition of Ulvaria oxysperma (Kützing) Bliding, Ulva lactuca
(Linnaeus) and Ulva facisata (Delile). Brazilian archives of biology and technology 47:49-55.

24. Habig C., Debusk T.A., and Ryther J.H. 1984. The Effect of NitrogenContent on Methane Production by the Marine-Algae GracilariaTikvahiae and Ulva Sp. Biomass 4:239-251.

25. Briand X. and Morand P. 1997. Anaerobic digestion of Ulva sp. 1. Relationship between Ulva composition and methanisation. Journal of Applied Phycology 9:511-524.

26. Morand P., Briand X., and Charlier R.H. 2006. Anaerobic digestion of Ulva sp 3. liquefaction juices extraction by pressing and a technicoeconomic budget. Journal of Applied Phycology 18:741-755.

27. Bruhn A., Dahl J., Jensen P.D., Nielsen H.B., Nikolaisen L.S., Rasmussen M.B., and Thomsen A.B. Biofuels from Ulva lactuca. In prep. for Bioresource Technology

28. Habig C., Andrews D.A., and Ryther J.H. 1984. Nitrogen Recycling and Methane Production Using Gracilaria-Tikvahiae - A Closed System Approach. Resources and Conservation 10:303-313.

29. Courtesy of own data from Power Ventures, Milano, 2010, Via Tamburini, 6, 20123 Milano, www.powerventures.it.

30. Department of soil science of North Carolina university. Poultry Manure as a Fertilizer Source, North Carolina Cooperative Extension Service Publication AG-439-5. Last Web Update: December 1997 http://www.soil.ncsu.edu/publications/Soilfacts/AG-439-05/

31. John Gelegenisa, Dimitris Georgakakisb, Irini Angelidakic, Vassilis Mavrisa, Optimization of biogas production by co-digesting whey with diluted poultry manure, Renewable Energy 32, 2007, pp 2147-2160.

32. Kaparaju P., Ellegaard L., Angelidaki I., Optimisation of biogas production from manure through serial digestion: Lab-scale and pilotscale studies, Bioresource Technology N. 100, 2009, pp. 701-709.

33. Hamed M. El-Mashad, Ruihong Zhang, Biogas production from codigestion of dairy manure and food waste, Bioresource Technology $\mathrm{N}$. 101, 2010, pp. 4021-4028.

34. Xiao Wua, Wanying Yao b, Jun Zhu, Curtis Miller, Biogas and CH4 productivity by co-digesting swine manure with three crop residues as an external carbon source, Bioresource Technology, N. 101, 2010, pp. 4042-4047.

35. Global emission model for integrated systems, LCA software and database version 4.5 (GEMIS 4.5): biogas generic.

36. Latvian Environment, Geology and Meteorology Centre, http://www.meteo.lv/public/hidrometeo_dati.html

37. United Nations Framework Convention on Climate Change, http://unfccc.int/2860.php

\section{Francesco Romagnoli, Researcher, PhD student}

Institute of Energy Systems and Environment, Riga Technical University

Kronvalda blv.-1, LV1010 - Riga (Latvia)

Phone: +371 28354151

e-mail: francesco.romagnoli@rtu

Dagnija Blumberga Dr. hab. sc. ing., Professor, Director

Institute of Energy Systems and Environment, Riga Technical University

Kronvalda bulvaris 1, Riga, LV-1010

Phone: +37167089901

e-mail: dagnija.blumberga@ rtu.lv

Emanuele Gigli

CIRPS, Inter-university Research Centre for Sustainable Development

University of Rome "La Sapienza"

Piazza San Pietro in Vincoli, 10 - 00184 Rome (Italy)

Phone: +3906 46204001

e-mail: emanuele.ggl@gmail.com

Francesco Romagnoli, Dagnija Blumberga, Emanuele Gigli. Biogāze no jūras makroalg̣ēēm: jauna vides tehnoloğija - dzīves cikla inventarizācija tālākai dzīves cikla novērtējuma veikšanai

N̦emot vērā Eiropas Komisijas un ANO Pārtikas un lauksaimniecības organizāciju centienus veicināt pētījumus par "nepārtikas" enerğijas kultūru izmantošanu otrās paaudzes biodegvielas iegūšanai, šī raksta galvenais mērkis ir analizēt inovatīvu biogāzes ražošanas procesu no jūras makroalg̣ēm, izmantojot fermentācijas procesus izpētes projektā Augustā (Sic̄ilijā, Itālija). Aḷges augšanas laikā spēj uzņemt barības vielas, un tādējāai var iegūt tālāk izmantojamu alığu biomasas ražu, kas radusies, asimilējot biolog̣isko atkritumu pārstrādes produktus. Izmantojot bioloǵiskos atkritumus, pārvēršot tos par alǵu barības vielām, iespējams novērst eidot bioloǵisko atkritumu negatīvo ietekmi uz vidi uz pozitīvu, mazinot eitrofikāciju un ietekmi uz klimata pārmaiṇām. Tikmēr tieši $\mathrm{CO}_{2}$ izmantošana, kas rodas ražošanas procesā, ir nozīmīgs faktors, kas nosaka aḷǵu augšanas ātrumu.

Faktiski, makroalǵes izmantošana kā vienojošu posmu starp biolog̣isko atkritumu pārstrādi un enerǵijas ražošanu lauj izmantot biologiiskos atkritumus ar augstu slāpekḷa un fosfātu saturu, radot $\mathrm{CO}_{2}$ uztvērēju oglekḷa kvotu tirdzniecībai, un izvairoties no kūtsmēslu pārstrādes izmaksām, pretim liekot makroaļgés kā labu peḷnu nesošas „nepārtikas" enerğijas avotu biomasas un enerǵijas ieguvei. 
Rakstā sniegti pirmie aprēķini un pien̦ēmumi dzīves cikla inventarizācijai, lai tālāk izstrādātu pilnu dzīves cikla novērtējumu, kas nepieciešams galīgam makroaļgu ražošanas ietekmes uz vidi novērtējumam.

Rakstā veikti teorētiski aprēķini par biogāzes un biometāna ražošanu, audzējot jūras makroaḷges Ulva Prolifera atklātos dīķos, par barības vielām aļgēm izmantojot biologiskos atkritumus (putnu mēslus), un raksturotas ieejošās un izejošās produktu un piesārnojuma plūsmas jūras alı́gu audzēšanas procesā, pamatojoties uz literatūras datiem un eksperimentālo analīzi. Pētījuma galīgais mērḳis ir noteikt vides rādītājus un līmeņatzīmju sliekšņus.

Raksts atspogulo inovatīvu vides tehnoloğiju biogāzes un otrās paaudzes biodegvielas (škidrs biometāns) ražošanai pilnveidotā procesā, izmantojot sasaldēšanas tehnoloǵiju. Raksts arī cenšas izprast iespēju īstenot šo inovatīvo tehnologijas Latvijas apstāklos, tostarp sniedzot novērtējumu CO ${ }_{2}$ emisiju samazināšanai ar šīs tehnolog̣ijas palīdzību.

Франческо Ромагноли, Дагния Блумберга, Эмануэль Гигли. Биогаз из морских макроводорослей: новая технология - переучёт жизненного цикла для дальнейшей ОЖЦ

В свете последних попыток Европейской комиссии и Организации пищевого и сельского хозяйства усиливать и продвигать учения и исследовательские работы на тему непродовольственных энергетических зерновых культур для производства биотоплива второго поколения, главная цель этой статьи проанализировать инновационный процесс производства биогаза (через процесс ферментации), используя морские макроводоросли в качестве исходного сырья, в проекте пробной станции в Августе (Сицилия, Италия). Во время роста водоросли способны усваивать питательные вещества, таким образом, последующий сбор биомассы водорослей возвращает питательные вещества в виде биотходов. Использование биоотходов как питательную среду в фазе роста водорослей делает возможной трансформацию негативного влияния на окружающую среду в позитивное с точки зрения таких категорий как эйтрофикации и изменения климата. Тем временем, прямое использование СО 2 , произведённого в процессах работы электростанций, является важным фактором для скорости прироста биомассы водорослей.

По факту, использование макроводорослей как границу между биотходами и производством энергии позволяет использовать биоотходы напрямую и: очищать биотходы с высоким содержанием азота и фосфатов, использовать $\mathrm{CO}_{2}$ в пользу рынка квот на СО использования удобрений, использовать макроводоросли как высокопродуктивный непродольственный источник биомассы и энергии.

Первые расчёты и предположения для переучёта жизненного цикла для дальнейшей ОЖЦ показаны в этой статье с целью оценить конечное влияние на окружающую среду от станции.

Анализ оценивает теоретическую продукцию биогаза и биометана, используя морские макроводоросли Ulva Рrolifera, культивируемые в открытых водоёмах, и количество биоотходов (птичий помёт), используемых в роли питательной среды для водорослей; а также начинает характеризовать впуск и выпуск в культивации морских водорослей на основе учений и экспериментов из литературы. Последние намерение исследования определить индикаторы для оценки влияния на окружающую среду и необходимые этапы внедрения.

Статья направлена на презентацию новой технологии окружающей среды для производства биогаза и биотоплива второго поколения (жидкий биометан) после процесса усовершенствования с применением криогенной технологии. Статья делает первую попытку понять возможность внедрения этой инновативной технологии в контексте Латвии, включая первоначальную оценку возможного снижения уровня СО 2 эмиссий в условиях использования этой технологии. 
